Daniela Andonovska-Trajkovska ${ }^{1}$

Faculty of Education, Bitola, "St. Kliment Ohridski"

University of Bitola, Republic of Macedonia

Оригинални

научни рад

\title{
The Impact of the Students' Age on the Literary Text Analysis Approach: Teaching Methods and Approaches in Primary Education
}

\begin{abstract}
Literary text analysis is part of the Language Arts and The Language and Literature Curriculum in the primary education. Teachers are expected to practice different types of teaching methods depending on the age of the students, such as: demonstration, whole class work, reading and working on a text, discussion, conversation, students' oral presentations and creative writing. Students can also do literary analysis in groups, pairs, individually and in whole-class work. The aim of this paper is to answer the question whether teachers employ different teaching methods and approaches in the process of students' responses to literary texts and the literary text analysis depending on their age and if they prefer some of the methods over others relative to students' age.

We have collected the necessary data for this descriptive research by conducting surveys that were specifically designed for the purpose of the research with the random sample of primary school teachers in the Republic of Macedonia (total N=75). Descriptive analysis and ANOVA - single factor were used as well. The results have shown that the teachers practice different teaching approaches depending on the students' age in the process of literary text analysis in class, which is graphically presented and discussed in the paper. The results did not show any significant differences among the general teaching methods used in different classes in primary education. The methods and approaches that teachers use are compared to the ones that are considered to be part of the modern trends according to the latest research.

The results of the research will help scholars to build a broader picture of the literary analysis lessons in the primary school in the Republic of Macedonia regarding the teaching methods and approaches that are employed for the purpose of obtaining the age-appropriate classroom atmosphere. It will also contribute to the process of teacher reflections about the methods and approaches that they are using in order to improve the quality of teaching while bearing in mind the contemporary trends of building interactive classrooms in which the students are responsible for their own learning.
\end{abstract}

Keywords: teaching methods, literary text analysis, teaching approaches, primary education.

1 daniela.andonovska@uklo.edu.mk Copyright $\odot 2017$ by the authors, licensee Teacher Education Faculty University of Belgrade, SERBIA.

This is an open access article distributed under the terms of the Creative Commons Attribution License (CC BY 4.0) (https://creativecommons.org/licenses/by/4.0/), which permits unrestricted use, distribution, and reproduction in any medium, provided the original paper is accurately cited. 


\section{Introduction}

Literary text analysis in primary schools in the Republic of Macedonia is a part of the school subject Macedonian Language which consists of several teaching areas: Language, Literature, Expression and Creation, Media Culture, and Reading and Writing for Beginners (for the lower grades), Listening and Speaking ( $1^{\text {st }}$ grade). Literary text analysis in the primary education has specific aims: to develop the culture of reading and aesthetic awareness among the students, broaden the students' perspectives and enable rapport between the text and the reader, and to provide the students with the knowledge of theory of literature regarding the literary genres, the specific literary features of various literary texts, such as figures of speech, versification features, types of speech in drama texts, compositional elements of drama plot, the knowledge about the characters in narratives, etc.

The primaryschoolcurriculum in the Republic of Macedonia for the subject Macedonian Language is built upon the concept of identifying educational goals and objectives that are accompanied by educational contents and proposed methodical solutions. Teachers can decide whether they will follow the instructions that are in accordance with the educational goals, meaning that they can decide which teaching methods are the most appropriate to be used in the classroom.

Teaching methods are not easily defined, given the fact that pedagogical concepts may influence the conceptualization of the teaching method. According to the traditional definition, the term method refers to an activity that is clearly defined regarding the aim, the constituents and the implementation procedures, and the teachers should fully understand it in order to practice it in proper manner (Desinan, 2011:146). In addition, is it possible for the scholars to discuss the perfect teaching method that can be applied in many different areas of human learning?
As the human society develops, teaching methods also develop and change. The most common perception of the teaching practice is the process in which the student is expected to listen, absorb, receive, react, reproduce, and to repeat, as a result of the behaviorist influence. Thus, the methods such as lectures, conversations in which a teacher plays the main role as the owner of the knowledge, directly instructed individual work, and direct teaching are among the teaching methods and approaches most practiced in schools (Arbunić, A., Kostović-Vranješ, 2007; Pale, 2013). Behaviorists have created the educational approach based on the stimulus-reaction relationship, i.e. a teacher as an active subject that produces and gives knowledge, and a student as a passive object that receives knowledge, reacts, reproduces or paraphrases. The constructivist point of view, (Jančić and Hus, 2017) based on Piaget's work, takes into account the learner and his/her ability to construct knowledge, make meaning and absorb knowledge in order to make sense of it and to translate it into skills. Similarly, problem-based learning (PBL) is also proposed, based on the ideas of Dewey (2001) about the democratization of education and his notion of learning by doing, meaning that the child learns best from the experience, i.e. from everyday contexts. The problem-based learning is defined as a learning method which involves student-centered learning in small groups in which students are engaged in a situation that provokes their thoughts in order to solve specific problems. The process of providing answers as possible resolution to the problem is, in most cases, guided by an expert (Barrows, 1980).

On the other hand, transmissive teaching strategies are more economical and less timeconsuming, which places transmissive methodology among the most exploited contemporary methods (Desinan, 2011). Transmissive strategies are viewed as consisting of memory-based teaching methods, while the modern strategies - as consisting of the methods based on thought. The latter can take various forms, but they all have one main purpose 
The Impact of the Students' Age on the Literary Text Analysis Approach: Teaching Methods...

- to make the meaning or learning meaningful (heuristic approach, problem-based learning, discovery learning, research-based learning, etc.).

According to Maksimović and Stančić (2012), teachers consider monologue (lectures, description, explanation, etc.) and dialogue (conversation, discussion, etc.) as the most efficient verbal teaching methods, primarily because they are economical: teachers can cover a lot of teaching material in a short period of time, and they provide opportunities for teachers to work with many students. Maksimović and Stančić point out that the teachers who teach science use illustrative and demonstrative methods on a regular basis, while teachers of social sciences and humanities mostly resort to verbal methods. The authors also express their concern that the individualization of the teaching process is at a very low level because teachers do not consider the specific features of individual students when they choose the teaching methods to be used in the classroom. In addition, although pair work and group work provide students with the environment in which they can interact with each other, solve problems, and discover new things, verbal methods and frontal work (direct teaching) prevail in the classroom. Sert (2005) explores the advantages and disadvantages of pair work in comparison with individual work, and concludes that pair work enables students to obtain better results in terms of achieving educational goals in the English language and improving the quality of communication and interaction among the students.

It is also worth mentioning that the latest research on teaching methods, especially the studies involving the comparative analyses of the modern and traditional methods, favor the modern methods that take ICT into consideration (Matijević, 2000; 2014). For example, Francišković (2012) proves that the modern methods that include the multimedia teaching tools and the Internet as a source of information as a part of the localization of the text have a positive effect on the reception of the literary excerpts, students' interest in reading, and on motivating the students to read the whole books.

\section{Methods}

The aim of the research was to answer the question whether teachers use different types of work and teaching methods in the process of literary texts analysis relative to the students' age. We formulated the main hypothesis $\mathrm{H}$ as follows: The choice of the methodological approach to literary text analysis in the primary school classroom depends on the students' age. In addition, we formulated the auxiliary hypotheses: $\mathrm{H} 1$ - The implementation of the general teaching methods in the process of literary text analysis in the primary school classroom depends on the students' age, and $\mathrm{H} 2$ - The implementation of the specific types of students' and teachers' work in the classroom in the process of literary text analysis in the primary school classroom depends on the students' age. Therefore, there is one independent variable, the students' age, and two dependent variables, the implementation of the general teaching methods in the process of literary text analysis in the primary school classroom, and the implementation of the specific types of students' and teachers' work in the classroom in the process of literary text analysis in the primary school classroom. We also formulated the following hypotheses (H1.1.-H1.7.): The implementation of demonstration/ conversation/ discussion/ oral expression/creative writing/ lecture/ text as teaching methods in the process of literary text analysis in the primary school classroom depends on the students' age; H2.1.-H2.4: Using the whole class work/ pair work/ group work/ individual work in the classroom in the process of literary text analysis in the primary school classroom depends on the students' age.

The research data were obtained by using a specially designed questionnaire consisting of open, close and combined questions related to didactical and methodological issues, the articulation of primary school lessons dealing with the literary 
prose text analysis, as well as the time assigned for each activity. The teachers were asked to present the methodological approach that they use on a regular basis with their students.

The sample consisted of 75 primary school teachers $(\mathrm{N}=75)$ (early primary school teachers (Grades 1-4) and teachers of Macedonian language and literature (Grades 6-9)) in the Republic of Macedonia from Bitola, Prilep, Struga, Ohrid, Kavadarci, Strumica, Makedonski Brod, and Kichevo and the surroundings identified by random sampling.

The data were tested with ANOVA - single factor test, followed by the formulation of the null hypothesis that there is no difference in the usage of different teaching methods or different types of work in the classroom in each grade. Qualitative analysis was applied to describe the features of the methodological approaches used by the teachers.

\section{Results and Discussion}

In order to test $\mathrm{H} 1$ hypothesis, we tested H1.1H1.7 by formulating the null hypotheses (H1.1.0H1.7.0), assuming that there is no significant difference among the different primary school grades regarding the usage of seven different general teaching methods such as demonstration, text, discussion, conversation, lectures, oral expression and creative writing in the process of analyzing literary prose texts.

We failed to reject the null hypotheses H1.1.0H1.7.0, because of the p-value $>0.05$ in all 7 cases (Table 1-Table 7), and F1.1-F1.7 $<\mathrm{F}_{\text {crit }}$, $\mathrm{df}=(65,6)$ or $(64,6)$. In other words, we can reject the alternative hypotheses H1.1-H1.7 and conclude that the implementation of different teaching methods in the literary text analysis in primary education does not depend on the age of the students.

Table 1. Using Demonstration as a teaching method in analyzing literary prose texts ANOVA -

Demonstration

\begin{tabular}{lcccccc}
\hline Source of Variation & SS & df & MS & F & P-value & F crit \\
\hline Between Groups & 43.60033 & 6 & 7.266721 & 1.567492 & 0.170878 & 2.241716 \\
Within Groups & 301.3329 & 65 & 4.63589 & & & \\
\multicolumn{1}{c}{ Total } & 344.9332 & 71 & & & & \\
\hline
\end{tabular}

Table 2. Using Text as a teaching method in analyzing literary prose texts ANOVA-Text

\begin{tabular}{lcccccc}
\hline Source of Variation & SS & df & MS & F & P-value & F crit \\
\hline Between Groups & 252.2829 & 6 & 42.04715 & 1.312241 & 0.264644 & 2.244024 \\
Within Groups & 2050.703 & 64 & 32.04223 & & & \\
\multicolumn{1}{c}{ Total } & 2302.986 & 70 & & & & \\
\hline
\end{tabular}

Table 3. Using Discussion as a teaching method in analyzing literary prose texts ANOVA-Discussion

\begin{tabular}{lcccccc}
\hline Source of Variation & SS & df & MS & F & P-value & F crit \\
\hline Between Groups & 126.5462 & 6 & 21.09104 & 0.902501 & 0.49881 & 2.244024 \\
Within Groups & 1495.651 & 64 & 23.36955 & & & \\
$\quad$ Total & 1622.197 & 70 & & & & \\
\hline
\end{tabular}

60 
The Impact of the Students' Age on the Literary Text Analysis Approach: Teaching Methods...

Table 4. Using Conversation as a teaching method in analyzing literary prose texts

ANOVA-

Conversation

\begin{tabular}{ccccccc}
\hline Source of Variation & SS & df & MS & F & P-value & F crit \\
\hline Between Groups & 126.5462 & 6 & 21.09104 & 0.902501 & 0.49881 & 2.244024 \\
Within Groups & 1495.651 & 64 & 23.36955 & & & \\
Total & 1622.197 & 70 & & & & \\
\hline
\end{tabular}

Table 5. Using Lectures as a teaching method in analyzing literary prose texts ANOVA-Lectures

\begin{tabular}{ccccccc}
\hline Source of Variation & SS & df & MS & F & P-value & F crit \\
\hline Between Groups & 81.33951 & 6 & 13.55659 & 1.184389 & 0.325928 & 2.244024 \\
Within Groups & 732.5478 & 64 & 11.44606 & & & \\
Total & 813.8873 & 70 & & & & \\
\hline
\end{tabular}

Table 6. Using Oral Expression as a teaching method in analyzing literary prose texts ANOVA-Oral

Expression

\begin{tabular}{ccccccc}
\hline Source of Variation & SS & df & MS & F & P-value & F crit \\
\hline Between Groups & 110.3964 & 6 & 18.39941 & 0.805463 & 0.569416 & 2.244024 \\
Within Groups & 1461.97 & 64 & 22.84328 & & & \\
Total & 1572.366 & 70 & & & & \\
\hline
\end{tabular}

Table 7. Using Creative Writing as a teaching method in analyzing literary prose texts

ANOVA-Creative

Writing

\begin{tabular}{ccccccc}
\hline Source of Variation & SS & df & MS & F & P-value & F crit \\
\hline Between Groups & 59.5141 & 6 & 9.919017 & 0.617641 & 0.71539 & 2.244024 \\
Within Groups & 1027.81 & 64 & 16.05953 & & & \\
Total & 1087.324 & 70 & & & & \\
\hline
\end{tabular}

The chart below (Chart 1) shows that apart from text and conversation as the most frequently used teaching methods in all grades (3-9), teachers also use students' oral presentations, discussion and lectures in the process of analyzing literary prose texts. Demonstration and creative writing are the least used methods. Given that we did not reject the null hypotheses regarding the implementation of teaching methods in the process of analyzing literary prose texts, it could not be proved that there is a difference among the types of teaching methods that teachers use relative to the age of the students, which is quite surprising. For this reason, we conducted the qualitative analysis of the articulation of the lessons in each grade and discovered that though teachers may not use different methods, they do practice different variations of the very same method relative to the age of their students. For instance, teachers use text-method in the lower primary grades mostly for reading age-appropriate 
texts. Third-graders are still achieving the goals of the basic language literacy, i.e. they learn to be fluent readers and writers, whereas in the fourth grade, there are still students who have difficulties with reading and writing. Consequently, text reading in the lower grades usually amounts to reading aloud for the purpose of connecting the psycholinguistic and motoric skills that are necessary for reading. The students are still struggling with connecting the code and the meaning - both denotative and connotative. It is important to say that the first reading of the text is mostly done by teachers, which differs from the first reading in the higher grades where either a skilled student reads aloud the prose text or students are given some time to read the text individually. In some cases, the students are expected to have read the text at home as part of their home assignments. Conversation method is used differently in the lower and higher grades. Teachers pose very simple questions in order to check whether the students have understood the text in the lower grades, and then they proceed with more complex questions for the purpose of making personal connections with the text. In the higher grades, teachers help students to understand the text only by encouraging them to identify the unknown words, and after the words are explained by using specific strategies, they lead the students into a discussion about the aesthetical values of the analyzed text, the features of the characters from philosophical, psychological, sociological perspectives, the ethical issues found in the story, etc. Interestingly, the teaching time increases exponentially with the grades. In the beginning, students learn simple concepts of the literary theory, and later on, in the higher grades, they learn more complex concepts and definitions of the literary elements such as plot, characters, genre, literary devices, types of narration, and so on. Therefore, the time for lecturing increases. Demonstration as a method is rarely used by the teachers, while in the $9^{\text {th }}$ grade it is not even on the list of recommended methods. When it is used, especially in the lower grades, it usually amounts to teachers showing a picture at the beginning of the lesson in order to motivate the students for work. In most cases, teachers simply point to the picture in students' textbooks, which is not enough neither for the process of the text localization, nor for motivating students to read the text. Creative writing is a very

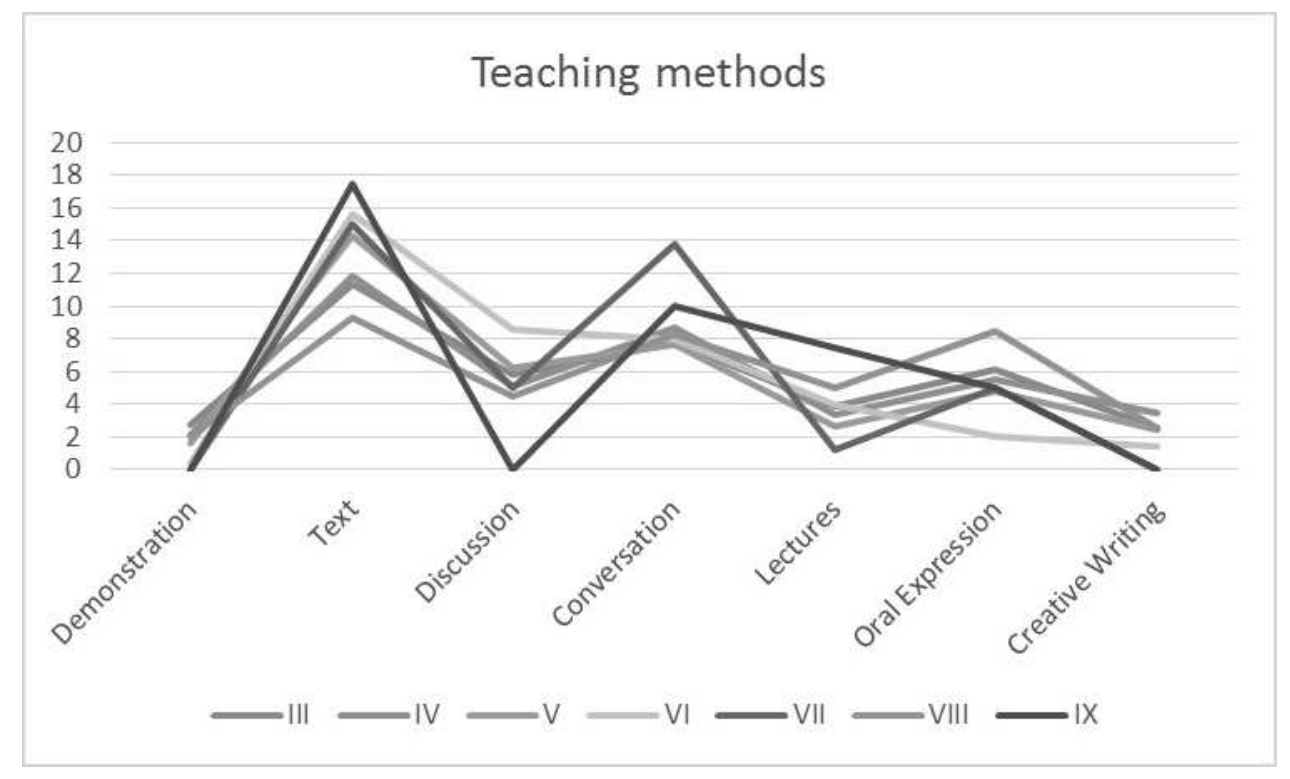

Chart 1. Teaching methods used by teachers for analyzing literary prose text in primary school 
The Impact of the Students' Age on the Literary Text Analysis Approach: Teaching Methods...

powerful method for provoking students' thoughts, but it is rarely used, especially in the higher grades.

In order to test $\mathrm{H} 2$, we tested $\mathrm{H} 2.1-\mathrm{H} 2.4$ hypotheses by formulating four null hypotheses that are assuming that there is no significant difference among the data gathered from all seven groups (grades 3-9) regarding the usage of the types of students' and teacher's work in class (social types), such as whole class work, pair work, group work and individual work. The variances of the groups were compared by using the ANOVA - single factor test.

The results indicate (Table 8) that the samples are not equal regarding the variances for the factor - whole class work $\left(\mathrm{F}_{2.1}(6,65)=3.735403, \mathrm{p}<.05\right)$. Therefore, we rejected the null hypothesis $\mathrm{H} 2.1 .0$, and accepted the alternative one - H2.1. We can conclude that the implementation of the whole class work in the process of literary text analysis in primary school depends on the students' age.

Table 8. Using whole class work as a social type of work in analyzing literary prose texts

\begin{tabular}{ccccccc}
$\begin{array}{l}\text { ANOVA-Whole } \\
\text { Class Work }\end{array}$ & \multicolumn{7}{l}{} \\
\hline Source of Variation & SS & df & MS & F & P-value & F crit \\
\hline Between Groups & 1821.452 & 6 & 303.5753 & 3.735403 & 0.002971 & 2.241716 \\
Within Groups & 5282.534 & 65 & 81.26976 & & & \\
Total & 7103.986 & 71 & & & & \\
\end{tabular}

We failed to reject the null hypothesis for the second factor - pair work (Table 9), because $\mathrm{F}_{2.2}(6,65)=1.668138, \mathrm{p}>.05$. Therefore, we rejected the alternative hypothesis $\mathrm{H} 2.2$ and concluded that practicing pair work in the process of literary text analysis in primary school does not depend on the students' age.

Table 9. Using pair work as a social type of work in analyzing literary prose texts ANOVA-Pair Work

\begin{tabular}{ccccccc}
\hline Source of Variation & SS & df & MS & F & P-value & F crit \\
\hline Between Groups & 221.2906 & 6 & 36.88177 & 1.668138 & 0.142769 & 2.23948 \\
Within Groups & 1459.23 & 66 & 22.10954 & & & \\
Total & 1680.521 & 72 & & & & \\
\hline
\end{tabular}

ANOVA-single factor test results (Table 10) show that we can reject the null hypothesis for the third factor and accept the alternative one $\mathrm{H} 2.3\left(\mathrm{~F}_{2.3}\right.$ $(6,67)=4.554279, \mathrm{p}<.05)$ that the samples differ from each other regarding the usage of the group work. In addition, we can conclude that practicing group work in the process of the literary prose text analysis depends on the students' age.

Table 10. Using group work as a social type of work in analyzing literary prose texts ANOVA-Group

Work

\begin{tabular}{ccccccc}
\hline Source of Variation & SS & df & MS & F & P-value & F crit \\
\hline Between Groups & 2150.695 & 6 & 358.4492 & 4.554279 & 0.000625 & 2.237312 \\
Within Groups & 5273.305 & 67 & 78.70604 & & & \\
Total & 7424 & 73 & & & & \\
\hline
\end{tabular}


We can also reject the null hypothesis for the fourth factor - individual work because of $\mathrm{F}_{2.4}(6,66)=2.293868, \mathrm{p}<.05$ as presented in Table
11. We can also conclude that practicing individual work in the process of literary prose text analysis depends on the students' age.

Table 11. Using individual work as a social type of work in analyzing literary prose texts

ANOVA-Individual work

\begin{tabular}{ccccccc}
\hline Source of Variation & SS & df & MS & F & P-value & F crit \\
\hline Between Groups & 681.9114 & 6 & 113.6519 & 2.293868 & 0.045147 & 2.23948 \\
Within Groups & 3270.034 & 66 & 49.54597 & & & \\
Total & 3951.945 & 72 & & & & \\
\hline
\end{tabular}

It should be noted (Chart $2-\mathrm{X}$ - types of social work, and $\mathrm{Y}$ - average time dedicated to each of the social types of work within the framework of a 40-minute lesson) that whole-class work is the most exploited type of social work in the process

of the literary prose text analysis, especially in the upper grades. The responses of the grade 9 teachers indicate that the whole-class work is the only type of social work in that they most frequently use in the classroom.

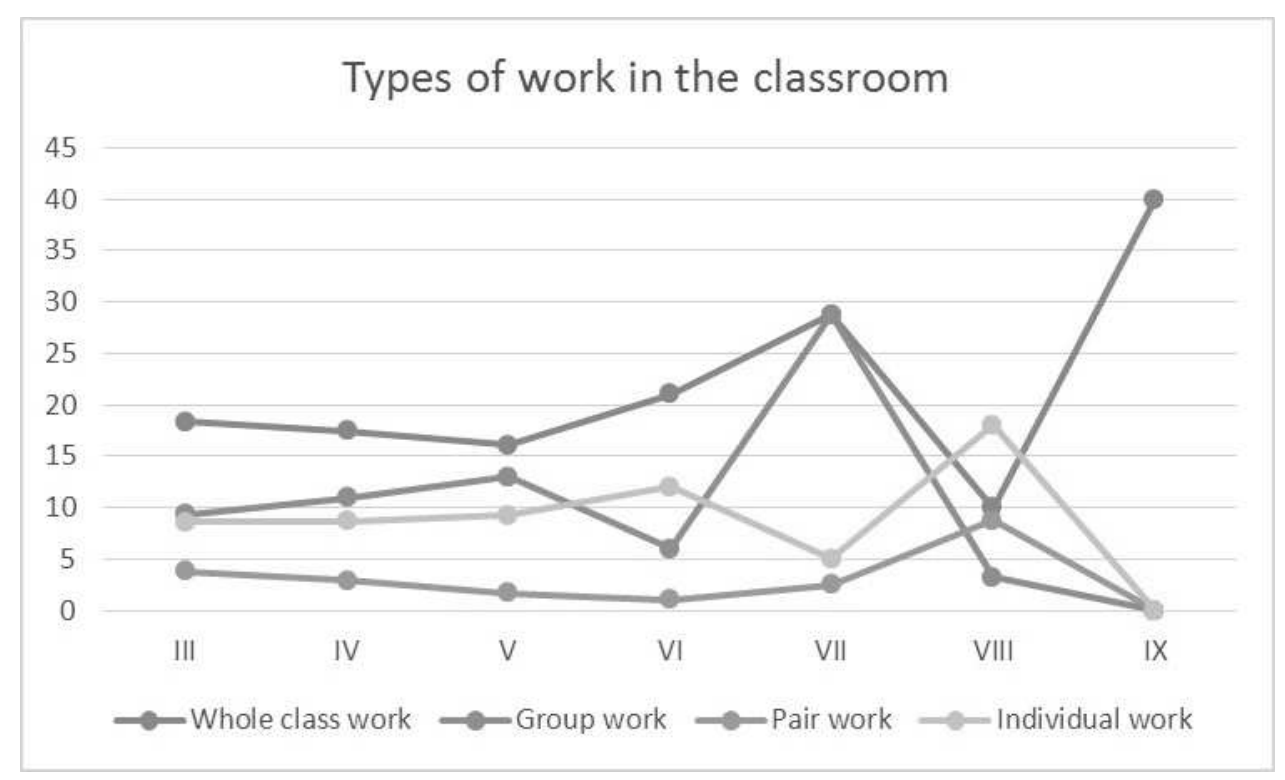

Chart 2. Social types of work used by teachers for literary prose text analysis in primary school

\section{Conclusion}

The aim of the research was to determine whether teachers use different teaching methods and social types of work in the classroom in the process of the literary prose text analysis relative to the age of their students. The results have shown that the teachers use the same teaching methods, i.e. they do not choose teaching methods according to their students' age, which is quite surprising. Text method and conversation are the most used methods among the teachers teaching various grades, but students' 
The Impact of the Students' Age on the Literary Text Analysis Approach: Teaching Methods...

oral presentations are used as well. Demonstration and creative writing are the least used methods.

In spite of the fact that the teachers use the same teaching methods, the research results show that they use many variations of the methods depending on the students' age. For instance, teachers use the text method in teaching early primary students for the purpose of developing their reading skills, which means that they use the method mostly for reading and the basic understanding of the text in the contexts in which the students read the text aloud many times during the lesson. On the other hand, teachers use the text method with older students mostly to enable them to develop a deeper understanding of the text and make critical inferences about the specific elements of the plot and the everyday contexts. In upper grades, students are frequently expected to read the text at home, whereas reading aloud in the class is rarely practiced. Conversation is a frequently used method, but for different purposes with younger and older students. Younger students are engaged in conversation with much easier questions (plot analysis and basic characterization of the characters in the text, localization of time and place in a text) than older ones (specific events in the plot, character analysis from various perspectives, text localization by making extra-textual connections).

We can conclude that the choice of the social types of work depends on the students' age (except for pair work). Group work is increasingly used starting from the 3rd to 5th grade, decreases unexpectedly in the $6^{\text {th }}$ grade, and reaches its peak in grade 7 . The fact that group work is rarely used ( $8^{\text {th }}$ grade) or not commonly used ( $9^{\text {th }}$ grade) in upper grades is quite surprising, bearing in mind the increased preparedness of the students to actively participate in the process of collaboration and cooperation in terms of their increased skills for managing information and increased responsibility for accomplishing the learning objectives. Pair work is the least used type of social work in the classroom in all grades, in spite of its advantages over individual work (Sert, 2005). Similarly, the most notable difference in using social types of work in the classroom is evident in the grades 6-9, and in the lower grades (3-5) when teachers use various types of social work in the class almost equally (except for the pair work). In the $6^{\text {th }}$ grade, teachers use whole-class activities most of the time, followed by individual and group work. Pair work is rarely used. In the $7^{\text {th }}$ grade, the whole-class work and group work are the most exploited social types of work, while individual and pair work are used least. The fact that whole-class work is the only commonly used social type of work in the classroom in the $9^{\text {th }}$ grade is rather surprising and calls for further research on this topic, especially if we bear in mind the results of the latest research in this field which show that students like to be engaged both socially an in cooperative learning (Terzić, 2012).

\section{References}

- Arbunić, A., Kostović-Vranješ, V. (2007). Nastava i izvori znanja. Odgojne znanosti. 9 (2), 97-111.

- Barrows, H. (1980). Problem based learning: An Approach to Medical Education. New York: Springer Publishing Company.

- Desinan, C. (2011). Current teaching and learning strategies. Metodicki obzori 6 (3), 145-152.

- Dewey, J. (2001). Democracy and Education: A Penn State Electronic Classics Series Publication. Retrieved May 17 2017. from https://nsee.memberclicks.net/assets/docs/KnowledgeCenter/BuildingExpEduc/BooksReports/10.\%20democracy\%20and\%20education\%20by\%20dewey.pdf

- Francišković, D. (2012). Applying Innovative Methodological Models in the Literary Text Localisation. Croatian Journal of Education. 14 (1): 73-102. 
- Jančić, P.; Hus, V. (2017). Teachers' Attitudes toward Constructivist Teaching of Social Studies in Primary Schools (With the Emphasis on Learning Forms). In: Proceedings of IAC-TLEl 2017, pp. 64-71.

- Maksimović, A. and Stančić, M. (2012). Nastavne metode iz perspektive nastavnika. Metodicki obzori 7(1), 69-82.

- Matijević, M. (2000). Hipermedijska obrazovna tehnologija u osnovnoj školi. In: Rosić, Vladimir (ur.). Nastavnik i suvremena obrazovna tehnologija (33-40). International conference: The Teacher and Modern Educational Technology, Gospić, Croatia, 8.- 9.06.2000. Rijeka: Filozofski fakultet u Rijeci.

- Matijević, M. (2014). Learning in the E-Environment: New Media and Learning for the Future. Libellarium. VII (1): 93-103.

- Pale, P. (2013). Intrinsic Deficiencies of Lectures as a Teaching Method. Coll. Antropol. 37 (2), 551-559.

- Sert, O. (Oct. 2005). A Comparative Analysis of Pair-work and Individual Assignments In two ELT Grammar Classes. Journal of Language and Linguistic Studies. 1 (2), 236-253.

- Terzić, F. (2012). ERR framework system and cooperative learning. Metodicki obzori 7 (1): 47-68.

\section{Резиме}

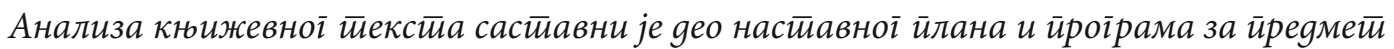

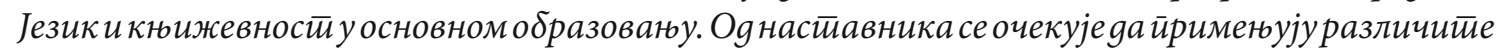

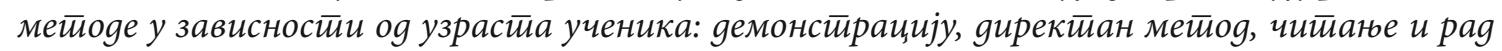

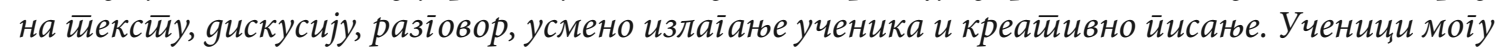

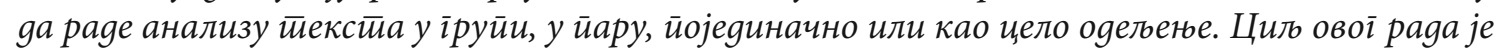

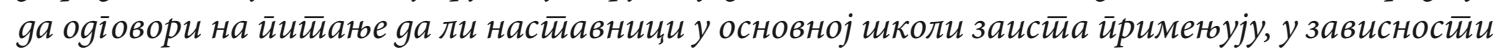

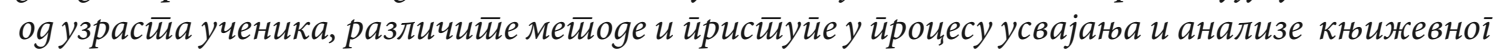

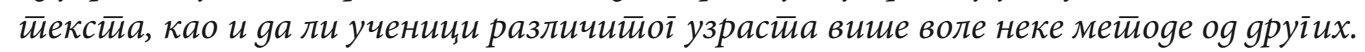

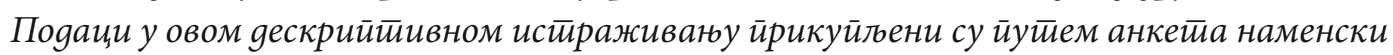
сачиғених за йойребе истираживана. Анкетиирағе је сировеgено на случајном узорку

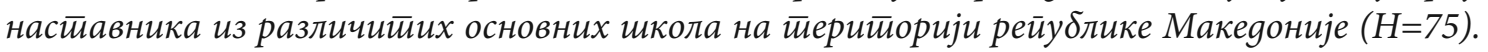
Постиуйии коришћени у овој стиуяији су дескрийтивна анализа и АНОВА јеgнобактиорски

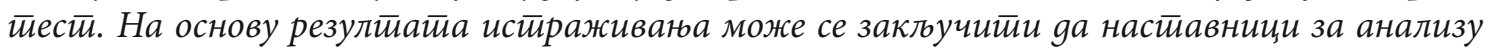

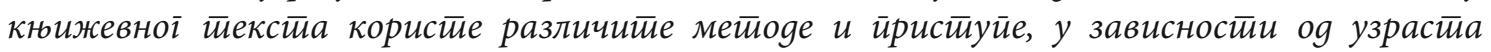
ученика. Метиоgе и йристиуйи које иримеюу анкетирани настивници уйоређени су са

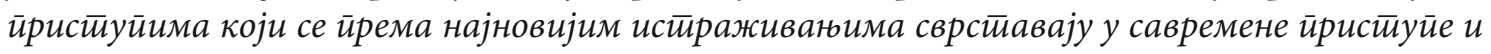
метиоле.

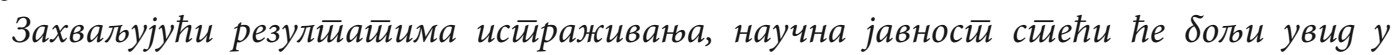
начин на који се врши анализа књижевноі текекста на нивоу основне школе у Макеgонији у йоілеgу йристиуйа и метиоgа йомоћу којих се у учиониии сиивара оgїоварајућа аймосфера за pag. Настиавницима ће ови резулитайи битии корисни каgа йреба gа се оиреgеле за оgређени

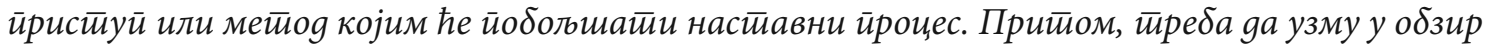

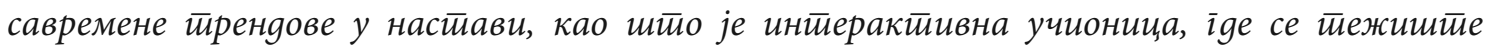
сийвља на оgїоворности ученика за сойсиввено ученье.

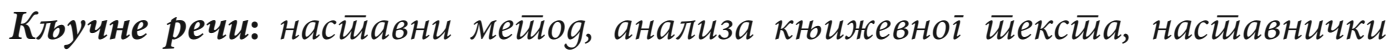
йристиуйи, основна школа. 